\title{
Choosing between the Truth and Participants' Rights: The Dilemma of a Qualitative Researcher
}

\author{
Suhailah Hussien \\ Kulliyyah of Education, \\ International Islamic University Malaysia \\ Kuala Lumpur \\ suhailah@iium.edu.my
}

\begin{abstract}
Making group work works in a classroom can be challenging, not only in the attainment of the objectives or results of the group work, but also of the whole process. This phenomenological study on the use of group work among pre-service teachers was initially aimed at exploring their experiences and understanding of group work as a process of learning and teaching. The study involved twelve final year female students enrolled in an undergraduate skill-based course. The students were given the task of organizing a field trip to an orphanage. They were provided with guidelines in planning and managing the trip, after which they were required to write a report. Students also documented their experience in a journal. Students' reports and journals were analysed, and resulted in three broad themes, which were group work as a constructive pedagogy, as a process of development or learning, and the challenges of group work in terms of group dynamics. However, the third theme, which is, the intra and inter group relations and interactions, put the researcher in a situation where she found herself in a dilemma to present either the truth of the study (i.e. the results), or to maintain the rights of the participants. This paper discusses how the researcher managed her dilemma through the negotiation of her roles as a researcher and course instructor. At the same time, she was compelled to redefine the boundaries of the study with the participants' consent. The paper reveals that a researcher's readiness to return to the field and to the participants is imperative in our attempt to ensure that the ethical issues of a research are carefully attended to.
\end{abstract}

Keywords: Qualitative study, phenomenology, researcher's roles, ethical issues, group work, group dynamics, pre-service teachers

\section{INTRODUCTION}

The definition and concept of good teaching in the modern age has required teachers to emphasise on students' needs and potentials. Today, the focus of teaching and learning is increasingly centred on students where teachers are expected to engage and involve them actively in meaning-laden activities. Teachers no longer tell students, but rather students have to experience learning by interacting with their peers and the environment. Active learning and meaningful meaning making tend to be more successful when they are done in a group than individually (Tan, Sharan, \& Eng, 2006; Abu Bakar, 2013). Such learning is also known in different terms like cooperative learning, collaborative learning, and reciprocal peer learning, or simply, as group work. Although these terms may differ, they share distinctive similarities in their objective, which is, working together in group on a task to achieve specific goals (Boud, Cohen, \& Sampson, 2001; as cited by Taqi \& Al-Nouh, 2014 in Gomlaksize, 2007). 
Previous studies have found that students learn best when they work actively in groups (Tan, Sharan, \& Eng, 2006). Working in groups helps students to learn better, motivates them, and encourages them to be more independent by taking more responsibility for their own behavior and learning. Such group work also retains their interest longer (Baines, Blatchford, Kutnick, Chowne, Ota, \& Berdonini, 2009; Murdoch \& Wilson, 2008). The benefits of group work are many, such as it "promotes teamwork, creativity, understanding one another, opportunities to learn and share experiences with others, and also learn new ways of doing things" (as cited by Thondlana \& Belluigi, 2014, p. 41 in Brownlie, 2001; Oakley, Felder, Brent \& Eljaj, 2004; Levin, 2005). A number of studies also have shown that it motivates learning (Baines et al., 2009), improves students' attitude and learning behaviours (Xou, 2013), teaches them to be responsible for their work, improves critical thinking, problem solving (Goodell, Cooke, \& Ash, 2012), communication and social skills, and helps to build new friendships (Goodell et al., 2012; Taqi \& Al-Nouh, 2014).

As an instructional method, group work is most useful when teaching subjects that involve hands-on or skill-based activities because students need to engage in collaborative activities where they help each other in understanding and challenging ideas through interaction and discussions. Such learning is based on constructivist theories of learning, which allow students to be engaged in learning through their experiences to induce cognitive conflict, and encourage students to develop new knowledge schemes. In this learning too students actively construct their meaning via social interaction (Hussain, Anwar, \& Iqbal, 2011).

Constructivist theory facilitates student learning by fitting in new learning experiences to prior knowledge, enabling students to construct new meaning. By learning in groups, students engage in actual learning experiences and also develop greater creativity, confidence, and leadership skills. However, in creating such learning experiences, teachers need to have greater preparation time and support. Teachers who intend to use group work need to give careful considerations on the planning and managing of the learning task and goal that the group is set to achieve.

Though a number of studies focus on teachers' implementation, perceptions and views of the group work method, very few have actually studied trainee teachers' experiences of learning and working in groups (Leonard \& McElroy, 2000; Dyson \& Rubin, 2003). There is a need to explore this aspect because trainee teachers are expected to create a student-centred learning environment and employ active learning pedagogies in their future classrooms. Since group work--through activities like collaborative, cooperative and project based learning-forms part of the basis for constructivist learning, I felt that it is essential to understand preservice or trainee teachers' experiences of the method by allowing them to go through the process experientially. Pre-service teachers may be induced to "champion" constructivist and student centred learning, but their knowledge and limited skills may be put to test when they face the complexities in the real classroom. So, in order to better prepare them for these complexities, the best way is to allow them to experience working in groups first hand. My study aimed at understanding the trainee teachers' views of the group work method, and whether it is a useful and effective pedagogy that they may want to consider in their future classrooms. Apart from that, the challenges that they face would also be a good lesson for them to consider when planning and using group work in their classrooms in the future.

\section{My Multiple Roles}

I played multiple roles in the study as the context of the study was one of my teaching courses. The course that was assigned to me was a course on teaching methods for pre-service teachers who were in their final year. In the first class of this course, I informed the students of my 
intention to conduct a study on group work as an instructional strategy that would involve the entire class. The aim was to explore their experiences in learning through group work. All of the students consented to participate and agreed that their journals (where they documented their experiences including views and feelings toward group work) would be used for the study. I was the course instructor, trip advisor and researcher, all in one. At the very onset, I had outlined the responsibility of each of my roles in order to be clear on the boundaries of my roles in the study. However, it was inevitable that the roles would coincide, consequently requiring me to negotiate the roles and redefine the boundaries in the study.

\section{The Study}

Teaching has been a constructive experience for me since it enables me to engage with and develop my students into individuals with potential. It has also helped me to research on the theories of learning that I intended my students to learn, acquire, and apply when they become teachers in the future. In return, my studies are also incumbent in informing my practices. Hence, my experience of teaching and research is cyclical in nature. Rather than becoming dichotomous, it has become a praxis that places me in a critical reflexive stance, where my roles as a teacher or instructor, and researcher were often blurred and tend to merge. However, in my effort to maintain and consider the ethics of my research, it is very important that I define my role as a researcher, separating it from the realm of teaching. This was needed particularly, when sharing and presenting my study to the public.

\section{Group Work Method}

In my attempt to explore the potentials of the group work method, I made sure of three specific aspects, which were the assignment design, group formation and assessment (Isaac, 2012). Prior to this research, I had been using the group work method every time I taught the course. My previous experiences had helped me to continuously improve the way I had been using the method. For instance, the first time I taught the course two years before, I had determined the group formation, but my decision brought about negative results in terms of team work relations, communication and work distribution amongst the members. Since then, I had allowed the students to have a free reign in group formation and only interfered when the need arose.

There are different types of group work such as Davis' (1993) three types, namely informal group work, formal group work and study team. In this regard, I would categorise my group work method for the course as formal group work because the groups were established to complete a project (i.e., managing and organizing the trip) throughout the semester, where they had to work together until the project was completed and graded.

In my effort to understand my students' experiences in going through the process of working in groups, I have decided to adopt Tuckman's (1977) model of group work to analyse the group development. Tuckman's five stages of group development consist of forming, storming, norming, performing and adjourning. The first stage, which is, the forming stage is where the group members learn about each other and the task at hand. Since the students had decided on the groups they would work in, I assumed they would go through the forming stage easily. Secondly, the storming stage explains that once the group members become familiar and comfortable with each other, the group members may begin to engage each other in argument due to disagreement about the task or even personality clashes. This stage is considered as an upsetting stage where tension, struggle and conflict sometimes occur.

Thirdly, the norming stage is the stage where group members establish clear rules-either implicit or explicit--about how they will achieve their goal. This is also the stage where 
they learn to resolve their differences and work closely together to complete the task at hand. The fourth stage is the performing stage that explains when group members have resolved their disagreements, they would focus on achieving the common goal until they become successful. Finally, the fifth stage, that is, the adjourning stage where the group task or project ends and the group disperses. Tuckman's five stages were useful in identifying the stages that my students' groups would be going through.

My study on group work can be divided into two phases albeit unintentionally. The first phase explored students' experiences of the group work method. Students' experiences were gauged from their individual journals. I also conducted a focus group discussion (FGD) with five students, where each group was represented by a student. The FGD was conducted after I collected all students' journals. These were then analysed thematically. The second phase of the study stemmed from the dilemma that I faced when dealing with the group dynamics of the students. This will be discussed in more detail in the discussion of my dilemma.

\section{The Course}

The course content was aimed at equipping pre-service teachers with the skills of using various teaching methods in the teaching of Moral Education, such as case study, moral dilemma, values clarification, storytelling, philosophical inquiry, problem-based learning, role play, simulation, game-based learning and educational visit. All methods taught in the course required students to work in groups. This means each group was required to demonstrate, in a mock classroom, how the various methods can be used.

For this paper, the focus will only be on students' group work on the method of educational visit. The assignment, which was organizing and managing an educational visit, required the students to form two types of group, a small group consisting of two to three students, and a large group, that is, the whole class. The main task of the large group was to develop and submit a working paper for the approval of the program to the faculty administration. They were also required to document all correspondences regarding the visit. For the small group tasks, each group was required to submit a report explaining their functions and responsibilities and how they had been fulfilled. Meanwhile, students were also given the task to document their experiences and feelings working in the large and small groups, throughout the organization of the visit. For the individual task, each student was required to document their experience engaging with the orphans. The completion and reports of all these tasks were then assessed and graded.

\section{METHODOLOGY}

\section{Participants}

The study involved all twelve students in the class as participants. They were all female and in their final year of undergraduate studies, specializing in Teaching English as a Second Language (TESL). The twelve students formed two types of group, a large group involving the whole class as the committee of the program, and small groups consisting of four groups including the main secretariat. The secretariat comprised the program manager (PM), the secretary, and the financial controller (FC). The other three smaller groups functioned like a bureau, namely the Bureau of Program and Transport, the Bureau of Food and Sponsorship, and the Bureau of Special Task and Welfare. The details of the participants, members of each bureau and the bureaus' roles and responsibilities are presented in Table 1.0. Pseudonyms are used to ensure the privacy and anonymity of the participants. 
Table 1

Details of Participants, Bureaus and Their Responsibilities

\begin{tabular}{|c|c|c|c|}
\hline No. & Bureau & Members & Roles and Responsibilities \\
\hline \multirow[t]{3}{*}{1} & $\begin{array}{l}\text { Main Secretariat (MS) } \\
\text { - } \quad \text { Program Manager } \\
\quad(\mathrm{PM})\end{array}$ & Lilo & $\begin{array}{l}\text { - Submitting a working paper for university } \\
\text { authority's approval; } \\
\text { - Overseeing and coordinating the bureaus and } \\
\text { their tasks; and } \\
\text { - Managing the overall running of the program }\end{array}$ \\
\hline & - $\quad$ Secretary $(\mathrm{Sec})$ & Mariah & $\begin{array}{l}\text { Taking minutes of meetings; } \\
\text { - Documenting all correspondences; and } \\
\text { from each bureau. }\end{array}$ \\
\hline & $\begin{array}{l}\text { - Financial Controller } \\
\text { (FC) }\end{array}$ & Mila & $\begin{array}{l}\text { Managing money received from sponsorships; } \\
\text { in the program. }\end{array}$ \\
\hline 2 & $\begin{array}{l}\text { Program and Transport } \\
\text { (BPT) }\end{array}$ & $\begin{array}{l}\text { Sarah } \\
\text { Marina } \\
\text { Sally }\end{array}$ & $\begin{array}{l}\text { Developing activities, modules and materials for } \\
\text { activities; } \\
\text { - Assigning facilitators for all activities; } \\
\text { - Ideoking a transport for the program; and } \\
\text { orphanage. }\end{array}$ \\
\hline 3 & $\begin{array}{l}\text { Food and Sponsorship } \\
(\mathrm{BFS})\end{array}$ & $\begin{array}{l}\text { Fizah } \\
\text { Hajar } \\
\text { Azie }\end{array}$ & $\begin{array}{l}\text { - Arranging food for the program; and } \\
\text { - Securing sponsorships for the program. }\end{array}$ \\
\hline 4 & $\begin{array}{l}\text { Special Task and Welfare } \\
\text { (BSTW) }\end{array}$ & $\begin{array}{l}\text { Akmar } \\
\text { Laily } \\
\text { Siti }\end{array}$ & $\begin{array}{l}\text { - Organizing and managing a charity drive for the } \\
\text { orphans; and } \\
\text { - Preparing gifts for the orphans and materials for } \\
\text { all activities. }\end{array}$ \\
\hline
\end{tabular}

The formation of the small groups or bureaus was done by the students according to their preferences. The MS and all bureaus had to also work together as a committee. The committee developed a working paper and submitted to the Dean through the instructor to obtain an approval for the visit. At the same time, each bureau worked in their small group according to their roles and responsibilities to ensure the smooth running of the visit, such as communicating with the orphanage, planning the activities for the orphans, managing the food and transport, and securing donations and sponsorships for the visit.

\section{Methods}

I decided that the best design for the study would be phenomenology because the primary aim of the study was to explore the experiences of the participants in undergoing the group work method in my course. Since the study's emphasis was on the participants' 'lived experience', thus a phenomenological study was considered appropriate to guide the inquiry (Pereira, 2012). Data for the first phase of the study involved students' individual journals and focus group discussion. Students had been briefed to document their experiences including their feelings and views of working in groups, carrying out their assigned tasks, completing their assignment on organizing the trip, and also when interacting with the orphans. Students had been informed that the journals will be part of the course assessment, and I also requested that they would be used as data for the study to which they had consented. 
For the journal writing, the participants had been advised to write in their journals regularly after each meeting with their groups, after each task had been completed, and whenever they felt that there was a need to share their feelings or events related to working on the trip. Students had also been briefed to document their writings in an organized manner. All writings were to include dates, time, place and topic. The topic refers to what the writing was all about such as an event, completion of a task, a meeting, or even a discussion. The journals were written throughout the semester for about 14 weeks. Students differed in the frequency and length of their writings. Some students wrote minimally, while some wrote quite lengthily and frequently. Some writings were scant, while some were extensive. Overall, the writings ranged between eight to twenty entries per journal. Since there were only 14 weeks, this indicates that some students wrote more than once in a week. However, for ease of documentation, I numbered the writings in the journal in the order of the entry dates. Details of the participants' codes for journaling and FGD are presented in Table 2.0.

Table 2.0

Participants' Codes for Journaling and FGD

\begin{tabular}{clcc}
\hline No. & Participants & $\begin{array}{c}\text { Codes for Journaling and } \\
\text { Number of Writings }\end{array}$ & $\begin{array}{c}\text { Codes for FGD (DU1 } \\
\text { - DU382) }\end{array}$ \\
\hline 1 & Lilo & LJ -20 & L \\
2 & Mariah & MRJ -18 & MR \\
3 & Mila & MLJ -10 & \\
4 & Sarah & SRJ -9 & MRN \\
5 & Marina & MRNJ -11 & \\
6 & Sally & SLJ -8 & F \\
7 & Fizah & FJ -17 & \\
8 & Hajar & HJ -16 & AZ \\
9 & Azie & AZJ -12 & LY \\
10 & Akmar & AKJ -10 & \\
11 & Laily & LYJ -11 & STJ -13 \\
12 & Siti & & \\
\hline
\end{tabular}

The focus group discussion (FGD) was conducted at the end of the semester after the trip and all assignments regarding the trip were submitted. The FGD involved two students from the MS, two from BFS, one from BPT and another from BSTW totaling six students. They were Lilo, Mariah, Marina, Fizah, Azie and Laily. These students participated in the FGD on a voluntary basis. The FGD ran for about 108 minutes. Although the purpose of the FGD was to gather deeper information on the students' experiences, it also functioned as a triangulation to the information acquired from students' journals and my observation of students' process of working in groups. Since I had already analysed students' journals, I was able to probe deeper into areas of concern, particularly the challenges that students faced when working in groups.

Both types of data, students' journals and FGD were then analysed thematically. The analysis began with the identification of recurring codes that were meaningful, and reflected students' experiences, feelings and also views. These were then analysed across the different participants and also across the different data types to examine the connections and the 'unfolding' of the themes to piece them into a meaningful picture. Analysing the data this way also enabled the different data types to be converged into a meaningful picture. The analysis was also guided by Tuckman's model of stages of group development.

In my effort to establish the credibility and rigour of the data, I made a point to do 'member checking' where I met the students involved in the FGD to show them the transcriptions and analyses. Apart from that, my plan to use two types of data, students' journals and FGD as a method of triangulation also gave me some assurance on the issue of rigour and trustworthiness of the data. Finally, peer debriefing was employed where I engaged a colleague 
to ascertain the credibility of the data. It was at this stage that I experienced a dilemma, particularly when I was refining the third theme on the group dynamics.

\section{ANALYSIS AND DISCUSSION OF RESULTS}

Since the main aim of the paper was to discuss the dilemma that I encountered in the second phase of the study, hence the analysis and discussion of the first phase will not take centre stage, but rather it is discussed briefly to pave the discussion to my predicament.

\section{The First Phase}

Generally the first phase of the study generated three broad themes, which were students' experiences of group work as a constructive pedagogy, as a process of self-development, and the challenges of group work in the form of group dynamics. Students felt that group work was constructive because it allowed them to think, learn and perform better in the assigned tasks (LJ11, STJ13, L-DU10, MRN-DU11, AZ-DU12). All of the students agreed that group work method facilitated better learning (SRJ4, SLJ3, AKJ5, L-DU11, MRN-DU11, AZ-DU12, LYDU13). Since more heads are better than one, they felt that working in groups enabled them to understand the content and task better, helped them to complete the task more efficiently and strategically, and build or scaffold on their friends' ideas (FJ3, AZJ5). In this sense, the group work strategy is considered important because it helps students to learn better and provide a good experience of learning on the task.

The second theme indicates that my students view group work as a process to develop important skills such as becoming more critical of yet remaining tolerant of others' views, managing a task better, improving their interpersonal communication skills, teamwork, and solving problems (LJ19, MLJ9, MRNJ11, FJ 17, AZJ12, AKJ9, LYJ11, STJ10)

These skills are important to make them more employable in the job market. Although these students were trained to become pre-service teachers, they were not guaranteed a teaching position upon their graduation. Hence, they believed the skills that they acquired through the group work could help them in becoming more employable, especially when dealing with people and hands-on tasks (MRN-DU301, AJ-DU 305, AZ-DU310, LY-DU311).

The final theme, which was the challenges that they faced concerned the group dynamics, namely the intra and inter group interactions and relations within the small and also the large group. The most frequent and critical problem that they encountered was the lack of commitment of some members such as in attending meetings, following up on tasks and duties, and not communicating promptly with the other members (L-DU352, MR-DU353, MRNDU354, LY-DU356, AZ-DU358, F-DU359). Despite the voluntary group formation, 'free riders' were still prevalent among the small groups and in the large group. This shows that the presence of cliques among the group members, or belonging to a clique, does not guarantee high connectivity, commitment and conflict-free dynamics. This finding differs from Cummings (2010), who shows that positive attitude toward collaborative learning is the result of working with people who have established connectivity and positive relationships. However, she further asserts that problems such as "poor interpersonal skills and differences of opinions and views can be either avoided or at least reduced if students know how to work together effectively" (p. 42). Consequently, this led to a lot of delays in decision-making concerning the trip. It was also at this juncture that I faced a dilemma and was torn between my role as the course instructor and the researcher. 


\section{The Second Phase: My Dilemma}

While I was analyzing the final theme, which was the group dynamics, I discovered that two of my students had not been performing their tasks as assigned. One was a member of the Main Secretariat (MS), while the other was from one of the bureaus. Both students were reported to me by Lilo, the class monitor who also happened to be a member of the MS. Lilo's group member held an important role that dealt with correspondences with external parties. However, these were not done, which resulted in the delay of many important decisions for the trip. In the end, the concerned bureaus resolved the matter by taking charge of the tasks themselves.

Meanwhile, another student who was a member of one of the bureaus also caused some problems in her lack of commitment in executing her assigned task. Her failure to deliver the task assigned to her as agreed in her group forced her group members to seek the assistance from the whole committee. To some extent, it disrupted the planning and management of the program. All the information about these students came to my knowledge from direct reports by the group members and through dissatisfaction expressed in students' journals.

\section{Resolving My Dilemma: Returning to the Field}

As the course instructor, these were two problems I discovered from students' reports and my consultations with them. The information did not only come from the affected group members, but also from those of other groups whose tasks were equally hampered by the two students' lack of commitment. However, these problems recurred in the midst of fulfilling my role as the researcher. Some of the conflicts which were actually sourced by the two students were shared in their respective journals.

In my attempt to triangulate the nature of the group dynamics, I decided to refer to the bureaus' reports. In order to do this, I had to approach the whole class and asked for their consent to make use of their small groups' report as part of my data. However, I received a visit from the bureau members (who were affected by their member's lack of commitment) and requested that their small group report to be excluded from the study. They informed me that the report was written by the 'problematic' member and they were not happy and disagreed with some of the content in the report. They claimed that the report was not truthful and wanted to submit a new group report, which described the true nature of their group work process and also their problem. However, their problematic member was not informed about the group's meeting with me, or about their intention to submit a new group report.

\section{Negotiating Multiple Roles and Redefining the Boundaries}

It was at this particular point that I realized as the researcher, I would welcome the report because it would be very useful for my triangulation effort. Since I had started with my analysis, and had discovered the conflict in the group dynamics, it would be a significant piece of data for the whole study. However, putting on the cap of the course instructor, I would prefer it if the bureau would submit the report as a group. Since my intention of conducting the group work method was to also allow the students to learn how to manage group work, I believed that accepting the second report without their friend's knowledge would not be fair to her. Furthermore, I feared that my decision would give different signals or indication as to what was acceptable and what was not when dealing with problems in group work.

What is acceptable at that point of time was to let the students learn to manage differences in their group regardless of what the majority felt, and also decide what they considered as 'right'. To some extent, I believed that managing disagreement is important in 
ensuring the success of group work. Referring to Tuckman's five stages of group work, it is clear that the group did not progress through all the stages smoothly although the assigned task was completed and their group had dispersed.

This situation also indicated that the group dynamics had been affected to the extent that the established relationship became soured in the process of working in their group. Although I failed to identify the true reason for this consequence of distrust among students who had already established a good relationship, I realized that one way of avoiding this situation in the future is to outline the roles of each group member explicitly, and delineate the penalty for members' lack of commitment, which should be done in consensus as suggested by Huff, Cooper, and Jones (2002).

I finally decided against accepting the second report from the students. This decision was made eventually, because as a researcher, I realized that I also need to ensure the rights of the problematic student as a participant in the study. Since I had to also ensure the other two members' rights as participants, I discussed the possible risks and consequences of the second report on their friend's rights. Eventually, they decided to exclude the first and second group reports from the study. The problematic student was informed of her members' decision and agreed with their decision. Hence, the first report was only accepted as the assignment for the course, but not as data for the study.

My decision was also based on the consideration of the aim of the study, which was initially to understand students' experiences of the group work method. I felt that it was important to focus on this particular aim rather than exposing foul play and drama in the group work method. To investigate on this issue would take another study altogether.

\section{Lessons Learned from the Study}

\section{On Being Ethical}

In the end, I decided that presenting the theme of group dynamics does not require the exploration of participants' deficiencies or weaknesses. What is important is to dissect the kind of conflicts and how they were resolved by the students in their group. Many lessons were learnt from this experience; one in particular is my readiness to change directions and return to the field when the need arises. Another lesson was to question my conscience when fulfilling my multiple roles. In this study, I realized that my role as a course instructor coincided with my role as a researcher. Although from the beginning I had defined the boundaries of my different roles, I realized that I had to redefine them for the benefit of my students and participants. I realized that I was compelled to be the 'peacemaker' between my students for the sake of their self development and positive learning experience of working in a group. Although I was not sure how much I was of help in the reconciliation process, I did emphasize to the students the importance of trust and openness even if it means hurting their relationship and friends.

\section{Improving Group Work}

The success of working in a group to some extent depends on students' working style preferences and group dynamics (Arnold, Ducate, \& Kost, 2012). 'Free riders' and 'social loafers' are a challenge to effective group learning, yet they are inevitable. For this reason too, a number of studies indicate students' reluctance and pessimism to work in group (Arnold et al., 2012; Taqi \& Al-Nouh, 2014). As the course instructor, I had opted to give students' the freedom to form their own groups; however, the problem of students' lack of commitment and limited participation still occurred. Some studies suggest that another way to improve the group work method is to ensure that there is an activity that allows the group members to bond when completing a task (Sutherland \& Stroot, 2010). I had already taken this measure where I 
continued to use the same small groups in other assignments in the course apart from organizing the trip. Yet, this was not sufficient in establishing the bonding with regard to the task at hand.

The complexity of the group dynamics has also made me more cautious to monitor students' process of working in group and completion of the task in stages. The study has taught me that in future, I should suggest to group members the need to draw up a contract describing in detail each member's role and responsibility. This contract needs to be submitted to me as the course instructor so that I can develop milestones for individual member's short term goals and targets that each has to meet according to his roles and responsibility. The milestones can also be used to assess and capture students' genuine individual performance while working in groups.

Following Isaac's reflection in her study (2012), when she said "even flawed group work serves students well" (p. 88), I have to agree with her line of thought. Sometimes students need to learn the hard way because the 'memorable' experiences, whether good or bad, may leave an indelible mark in their lives. This is after all the best way of learning, that is, through memorable experiences.

\section{CONCLUSION}

At the onset, my study was aimed at exploring my students' (future teachers) experiences of working in groups. Although the objectives of the study were successfully addressed, I learned something more valuable, which was, the possibility of having to negotiate between my multiple roles as the course instructor and researcher in the study. My conscience as the researcher and course instructor was also challenged when I had to decide on the next step of action with regard to my students' conflict. However, I discovered that being ethical is important as it ensures the rights of the participants even at the expense of 'good data' and 'significant findings'. Furthermore, I learned that as a researcher, I should always be ready to return to the field and negotiate with my participants. In spite of all these setbacks, they did not deter me from pursuing my research qualitatively simply because of the rich, and unexpected yet valuable lessons that I gained from it.

\section{Acknowledgment}

This work was supported by IIUM Research Initiative Grant Scheme (RIGS16-373-0537). 


\section{REFERENCES}

Arnold, N., Ducate, L., \& Kost, C. (2012). Analyzing group dynamics and revision processes in Wikis. CALICO Journal, 29 (3), 431-448.

Baines, E., Blatchford, P., Kutnick, P., Chowne, A., Ota, C., \& Berdonini, L. (2009). Promoting effective group work in the primary classroom: A handbook for teachers and practitioners. New York: Routledge.

Boud, D., Cohen, R. \& Sampson, J. (2001). Peer learning in higher education: Learning from and with each other. UK: Kogan Page Ltd.

Cumming, J. (2010). Student-initiated group management strategies for more effective and enjoyable group work experiences. Journal of Hospitality, Leisure, Sport \& Tourism Education, 9 (2), 31-45.

Curseu, P. L., Janssen, S.E.A., Raab, J. (2012). Connecting the dots: social network structure, conflict, and group cognitive complexity. Higher Education, 63 (5), 621-629.

Dyson, B., \& Rubin, A. (2003). Implementing cooperative learning in elementary physical education. Journal of Physical Education, Recreation \& Dance, 74 (1), 48-55.

Goodell, L.S., Cooke, N. K., \& Ash, S. L. (2012). Cooperative learning through in-class team work: An approach to classroom instruction in a life cycle nutrition course. NACTA Journal, 56 (2), 68-75.

Huff, L. C., Cooper, J., \& Jones, W. (2002). The development and consequences of trust in student project groups. Journal of Marketing Education, 24 (1), 24-34.

Isaac, M. L. (2012). "I hate group work!" Social loafers, indignant peers, and the drama of the classroom. English Journal, 101 (4), 83-89.

Hussain, S., Anwar, S. \& Iqbal, M. (2011). Effect of peer group activity-based learning on students' academic achievement in Physics at secondary level. International Journal of Academic Research, 3(1), 940-944.

Kaufman, D. \& Moss, D.(2010). A new look at preservice teachers' conceptions of classroom management and organization: Uncovering complexity and dissonance, The Teacher Educator, 45, 118-136, DOI: 10.1080/08878731003623669.

Leonard, J., \& McElroy, K. (2000), What one middle school teacher learned about cooperative learning. Journal of Research in Childhood Education, 14 (2), 239-245.

Xue, M. (2013). Effects of group work on english communicative competence of chinese international graduates in united states institutions of higher education. The Qualitative Report, 18, 1-19.

Murdoch, K., \& Wilson, J. (2008). Helping your pupils to work cooperatively. United Kingdom: Routledge.

Pereira, H. (2012). Rigour in phenomenological research: reflections of a novice nurse researcher. Nurse Researcher, 19 (3), 16-19. 
Sutherland, S., \& Stroot, S. (2010). The impact of participation in an inclusive adventure education trip on group dynamics. Journal of Leisure Research, 42 (1), 153-176.

Tan, I.G.C., Sharan, S., \& Eng, C.K.E. (2006). Group investigation and student learning: An experiment in Singapore schools. Singapore: Marshall Cavendish Int.

Taqi, H.A., \& Al-Nouh, N.A. (2014). Effect of group work on EFL students' attitudes and learning in higher education. Journal of Education and learning, 3 (2), 52-65.

Thondlana, G., \& Belluigi, D.Z. (2014). Group work as 'terrains of learning for students in South African higher education. Perspectives of Education, 32 (4), 40-55.

Tuckman, B. \& Jensen, M. (1977). Stages of Small Group Development. Group and Organizational Studies, 2, 419-427. 